\title{
Preparation and Characterization of Porous Ceramic Membranes for Micro-Filtration from Clay/CuZn Using Extrusion Methods
}

\author{
$\operatorname{Muh} \operatorname{Amin}^{1 *}$ and Muhammad Subri ${ }^{1}$ \\ ${ }^{1}$ Mechanical Engineering Department, Universitas Muhammadiyah Semarang, Indonesia
}

\begin{abstract}
In this study, fabrication and characterization of ceramic membranes preparation was carried out. Porous ceramic membranes were fabricated by extrusion process from different percentage composition of CuZn on (80 wt $\%$ Clay, $10 \mathrm{wt} \% \mathrm{TiO}_{2}, 5 \mathrm{wt} \%$ Carbon and $5 \mathrm{wt} \% \mathrm{PVA}$ ). The fabricated membranes were sintered at $900^{\circ} \mathrm{C}$ for 1 hour in an electrical box furnace with heating rate $10 \mathrm{C} / \mathrm{min}$ and holding time for 1 hour. Apparent density and porosity were determined by standar methods for ceramic materials. Phase composition of the ceramic support was established by X-Ray Diffraction analysis. SEM studies of the membranes added at different CuZn were carried out.
\end{abstract}

\section{Introduction}

Ceramic membranes were used in waste water technology and succesfull and possible applications cover all industries where media fillered, likely: chemical industry, metal industry (surface engineering), textiles (pupl and paper industry), food and beverages, recycling and environment [1]. Membrane application as the filtering of bacteria [2] and water treatment [3].

Commercialized porous ceramic membranes from alumina, zirconia, titania, and silica are not suitable for large scale application because these membranes are very expensive. In recent yeras, the preparation and potensial application of porous ceramic membrane on the basis of naturally occurring minerals such as zeolite, apatite, clay kaolinite, dolomite, have increasingly attracted intention for its low cost. The development of naturally mineral-based ceramic membranes can lead to a critical new technological revolution that existed through out the world [4].

Ceramic membranes are granular membranes and its are made from inorganic materials such as $\mathrm{Al}_{2} \mathrm{O}_{3}, \mathrm{TiO}_{2}$, $\mathrm{ZrO}_{2}, \mathrm{SiO}_{2}$, etc. or combination of these materials. Production of micro porous ceramic membrane filters also can be made by compressing and sintering of pyrex powder.

In contrast with polymeric membranes, ceramic membranes have excellent thermal and chemical stability wich makes them usable in high temperature membrane operations and aggresive environments. Also its were very stable mechanicals for many pharmaceutical industries or in water and waste water processing [5].

Fabrication of nanometer membranes from local kaolin and limestone from Algerian were processed by extrusion [6]. In these studies the dried tubular samples were sintered at various temperatures ranging between $800^{\circ} \mathrm{C}$ and $1100^{\circ} \mathrm{C}$ following this program:

$$
25^{\circ} \mathrm{C} \stackrel{2^{\circ} \mathrm{C} / \mathrm{min}}{\longrightarrow} 250^{\circ} \mathrm{C}(2 \mathrm{~h}) \stackrel{2^{\circ} \mathrm{C} / \mathrm{min}}{\longrightarrow} 800-1100^{\circ} \mathrm{C}(3 \mathrm{~h})
$$

The preparation of the natural zeolite membrane from Kralevo's deposits can be produced into multilayer ceramic membranes for microfiltration at low sintering temperature of $800^{\circ} \mathrm{C}$. The obtained by dip-coating membranes are characterized with good adhesion between the support and layers, high porosity of the support membrane and very uniform pore distribution [7].

Ceramic membranes made from alumina have been successfully performed [8]. Its were processed by using the extrusion method. Starting alumina dough was consisted of 71 wt.\% alumina powder mixed with 29 wt. \% of processing additives (hydroxypropylmethyl cellulose, strach dispersant, plasicizer (PEG, polyethylene glycol), lubricant and water). The alumina dough was extruded and dried. Then, the green extruded were sintered in the temperature range of $1300^{\circ} \mathrm{C}$ $1500^{\circ} \mathrm{C}$ for 2 hours. The increasing of sintering temperature, there was a slight change in particle morphology leading to particle coarsening and densification (less porosity).

Researcher use various porous ceramic membrane to support fabrication methods. Most membrane supports (commercial and home made) were fabricated by powder pressing, past processing, and collodial processing methods. A detailed classification is shown in Figure 1 [9]. Slip casting and dry pressing methods are widely used in lab scales, while the method in industry is extrusion [10].

\footnotetext{
* Corresponding author: amin@unimus.ac.id
} 


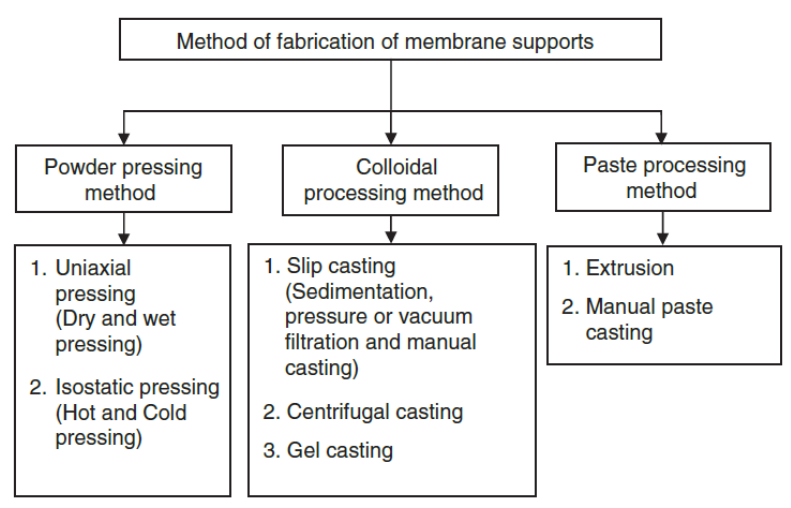

Fig. 1. Classification of the membrane support production methodes based on the precurcor aggregate state

The aim of this work is toward the development of low cost ceramic membrane. In order to obtain a low price in the process of making ceramics, one solution is to use local materials that have a high abundance. The use of the extrusion method is also easy and costeffective.

\section{Method}

\subsection{Raw materials}

The raw materials were used for in this study are Clay, $\mathrm{TiO}_{2}$, Black Carbon (BC), Polyvinyl Alchohol (PVA) and $\mathrm{CuZn}$. The raw materials are obtained from local Central Java, Indonesia, except PVA from China. The $\mathrm{CuZn}$ was obtained from industrial waste from $\mathrm{CuZn}$ craftsmen in Juwana, Central Java, Indonesia.

\subsection{Preparation of raw materials for obtaining of ceramic membranes}

The raw materials were used for this study were has been tested to obtain related information. All the studed materials were tested chemical composition in order to obtain chemical content information. All materials were prepared in the powder shape that passes filtered with 80 mesh, except PVA with 100 mesh.

\subsection{Membrane preparation}

Manufacturing of green body was done by preparing of 80 wt.\% Clay, 10 wt. $\% \mathrm{TiO}_{2}, 5$ wt. $\% \mathrm{BC}$ and 5 wt.\% PVA becoming dough. Then, the additive of CuZn was added to the dough with various of $0 \mathrm{wt} . \%, 10 \mathrm{wt} . \%, 20$ wt. $\%, 30$ wt. $\%$ and 40 wt. $\%$. It was processed to become the samples as shown at the following Table 1. The fabrication of the green body was printed by extrusion method of pressure $25 \mathrm{MPa}$. The details of the processing step of the membranes are displayed in Figure 2.

Prior to the extrusion process, all materials were mixed at the rotational speed of $64 \mathrm{rpm}$ for $30 \mathrm{~min}$. After that, its were continued for blending process with water addition of $20 \mathrm{wt} . \%$ and $5 \mathrm{wt} \%$ oil. The addition of oil has a purpose to facilitate the extrusion process and to avoid cracking on the surface of the created membrane material.

Table 1. Percentage composition of the raw materials

\begin{tabular}{|c|c|c|c|c|c|}
\hline Sample & $\begin{array}{c}\text { Clay } \\
\text { (wt.\%) }\end{array}$ & $\begin{array}{c}\mathrm{TiO}_{2} \\
(\text { wt.\%) }\end{array}$ & $\begin{array}{c}\mathrm{BC} \\
\text { (wt.\%) }\end{array}$ & $\begin{array}{c}\text { PVA } \\
\text { (wt.\%) }\end{array}$ & $\begin{array}{c}\mathrm{CuZn} \\
\text { (wt.\%) }\end{array}$ \\
\hline A & 80 & 10 & 5 & 5 & 0 \\
\hline B & 80 & 10 & 5 & 5 & 10 \\
\hline C & 80 & 10 & 5 & 5 & 20 \\
\hline D & 80 & 10 & 5 & 5 & 30 \\
\hline E & 80 & 10 & 5 & 5 & 40 \\
\hline
\end{tabular}

Raw Materials

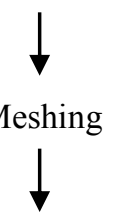

Compositions

(80 wt.\% Clay, 10 wt.\% TiO 2,5 wt. $\%$ BC +5 wt.\% PVA)

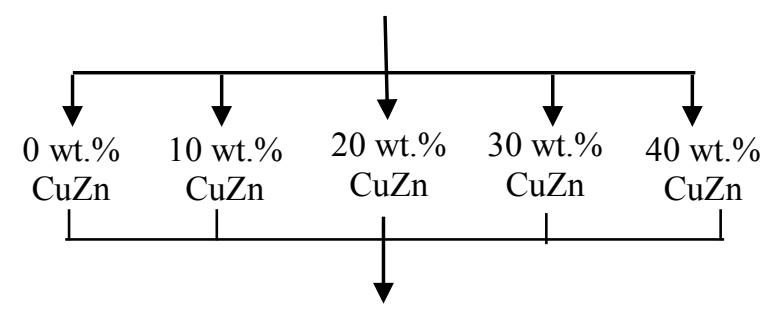

Addition of Water 20 wt.\%

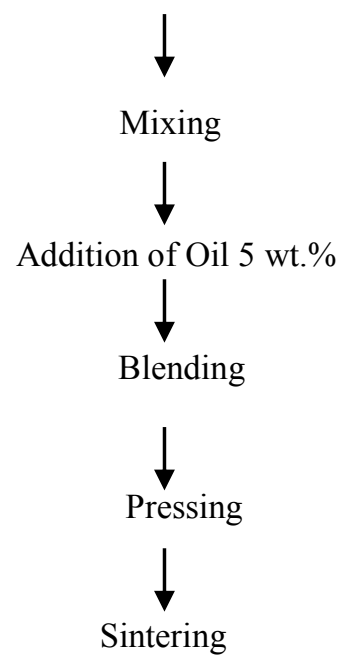

Fig. 2 Squential path for membranes preparation

Sintering process was done after the green body ceramic placed in the room temperature for 24 hours in order to obtain stability. The roles of sintering processed 
was done according to Figure 3. The process of sintering green body was done on the two stages. The first stage, sintering has done at temperatur $400^{\circ} \mathrm{C}$ by heating rate $5^{\circ} \mathrm{C} / \mathrm{min}$ and holding time for 0.5 hours. After that, the second sintering was carried out at a temperature of $900^{\circ} \mathrm{C}$ with heating rate $5^{\circ} \mathrm{C} / \mathrm{min}$ and holding time for 1 hour. The decreasing on tempetarure was done by turn off the button on furnace.

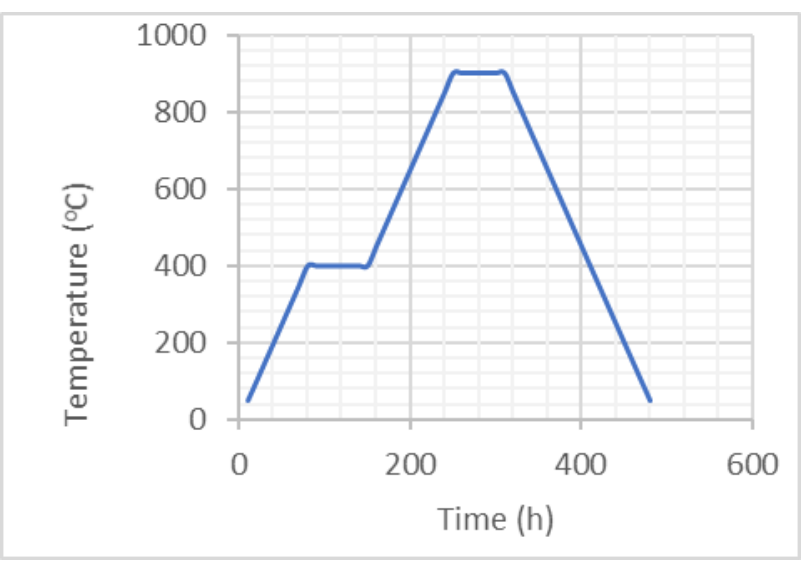

Fig. 3. Sintering temperature profile

\subsection{Characterization methods}

The result of Clay/CuZn membranes was tested for chemical composition, density, porosity, X-Ray Diffraction (XRD) and Scanning Electron Microscopy (SEM). The chemical composition of the row material was analyzed by ZAF Methode Standarless Quantitive Analysis.

The density test was calculated according to the Archimedes method by weighing the samples in the air and in the water. Weighing results in air and in water are used to determine density and porosity by using the following formula [11]:

Bulk Density $\left(\frac{\mathrm{g}}{\mathrm{ml}}\right)=\frac{\text { Mass in air }(\mathrm{g})}{\text { Volume of water displaced (ml) }}$

Apparent Porosity $(\%)=\frac{\text { Soaked mass }(\mathrm{g})-\text { Moss in air }(g)}{\text { Soaked mass }(\mathrm{g})-\text { Suspended mass }(\mathrm{g})}$

\section{Result and discussion}

The density test of pore ceramic membranes were calculated by the Archimedes method according to equation (1) wich was prepared with samples of $5 \mathrm{~mm} \mathrm{x}$ $5 \mathrm{~mm} \times 50 \mathrm{~mm}$. Based on figure 4 it can be seen that the increasing content of $\mathrm{CuZn}$ can be increase value of density. The highest density was achieved by ceramic membrane at more $\mathrm{CuZn}$ content because $\mathrm{CuZn}$ has higher density than all raw materials used ie $8.7 \mathrm{gr} / \mathrm{cm}^{3}$.

In addition of $\mathrm{CuZn} 10$ wt.\% showed a significant increase in density ie $4.59 \mathrm{~g} / \mathrm{cm}^{3}$, after which it will increase linearly as $\mathrm{CuZn}$ content increases. Material pore ceramic membrane without $\mathrm{CuZn}$ content sintered at $900^{\circ} \mathrm{C}$ with 1 hour holding time has a density of 1.96 $\mathrm{gr} / \mathrm{cm}^{3}$. So, in other words there is an increase of more than $100 \%$ by adding $\mathrm{CuZn}$ into the ceramic pore membrane material.

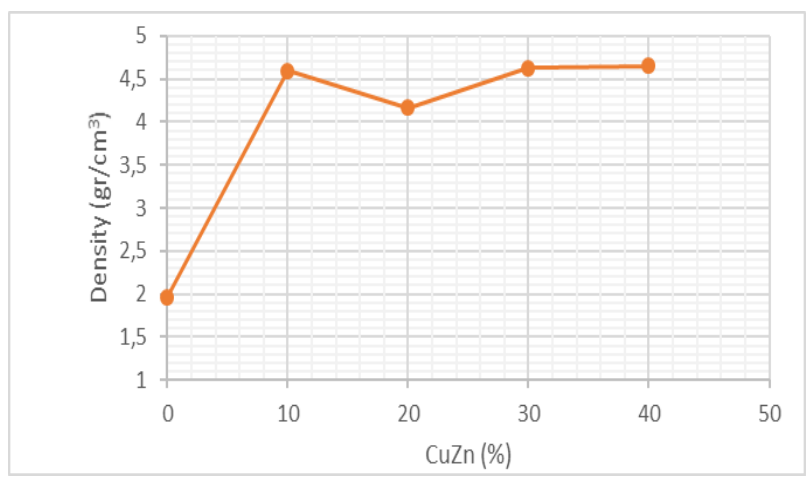

Fig. 4. Density of Clay/CuZn membrane at sintering $900^{\circ} \mathrm{C}$

Based on the porosity calculation by the equation (3) that increasing $\mathrm{CuZn}$ content on porous ceramic material can be increase the amount of material porosity. As in Figure 5, there is a significant increase of $\mathrm{CuZn}$ without content up to 10 wt. $\% \mathrm{CuZn}$ content of $44.58 \%$ ie from $44.58 \%$ to $66.67 \%$ or an increase of $49.52 \%$. After that, with increasing $\mathrm{CuZn}$ content, porous ceramic materials decreased porosity to 55.13 on CuZn content of $40 \mathrm{wt} . \%$. so the highest porosity with the addition of $\mathrm{CuZn}$ content is $66.67 \%$ on the addition of $\mathrm{CuZn} 10 \mathrm{wt} . \%$.

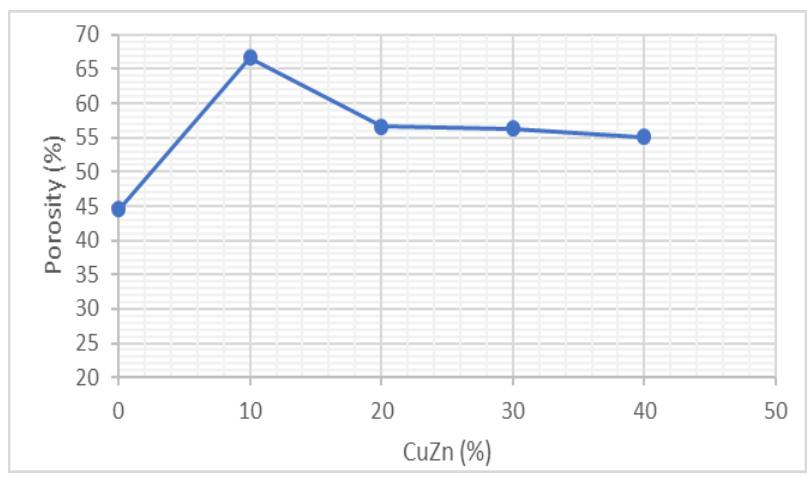

Fig. 5. Porosity of $\mathrm{Clay} / \mathrm{CuZn}$ membrane at sintering $900^{\circ} \mathrm{C}$

XRD Test results were performed with the following parameters: instrument $=6510(\mathrm{LA})$, Acc (Figure 6). Beratage $=20.0 \mathrm{kV}$, probe current $=1.0 \mathrm{nA}$, PHA mode $=\mathrm{T} 3$ and Real Time $=51.34$ seconds, Live time $=50.0$ seconds, Dead time $=2 \%$, Counting rate $=300 \mathrm{cps}$ and energy range $=0-20 \mathrm{keV}$. 


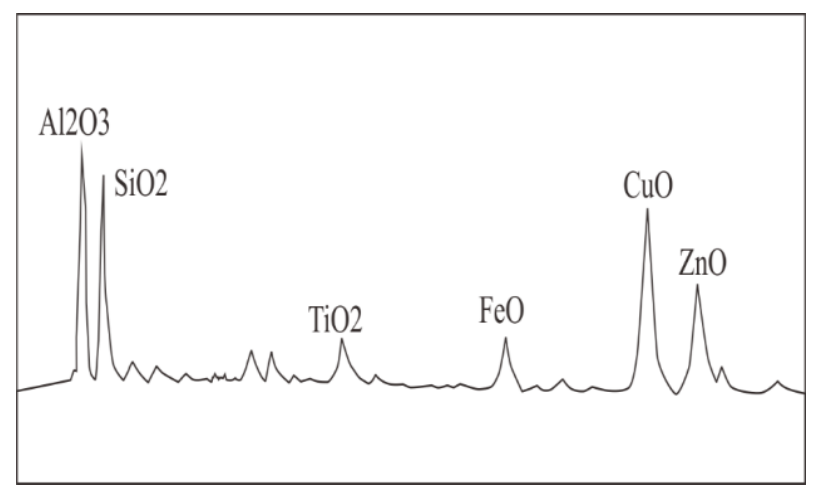

Fig. 6. X-ray diffraction pattern for membrane $10 \mathrm{wt} . \%$
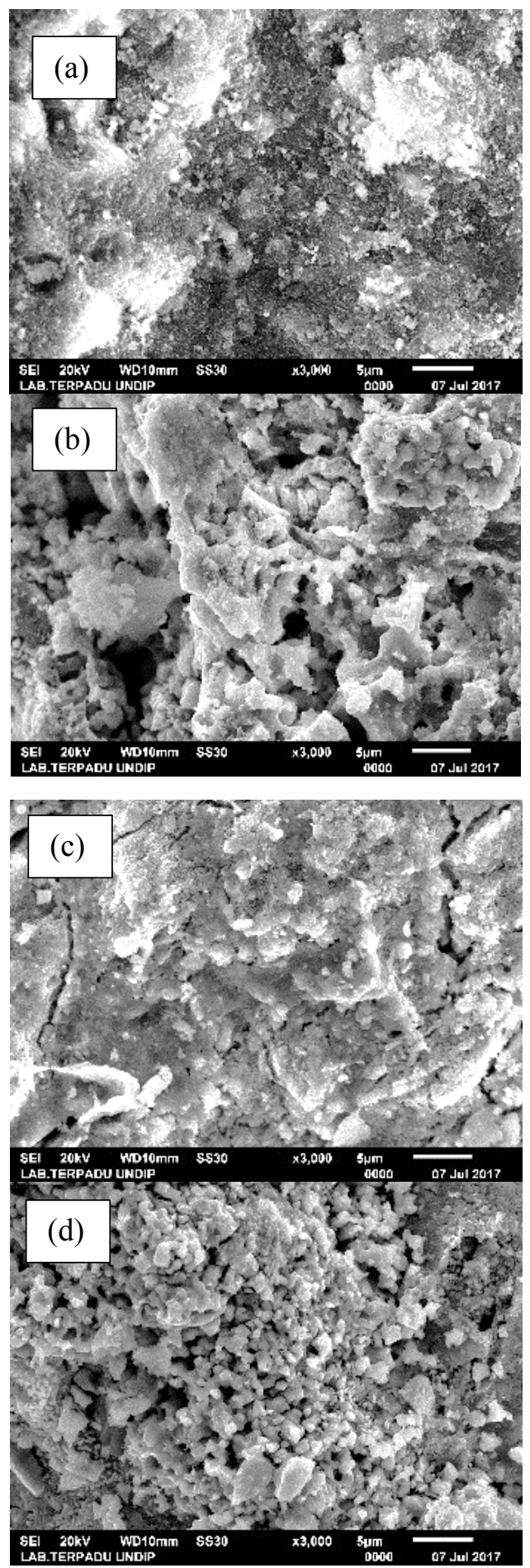

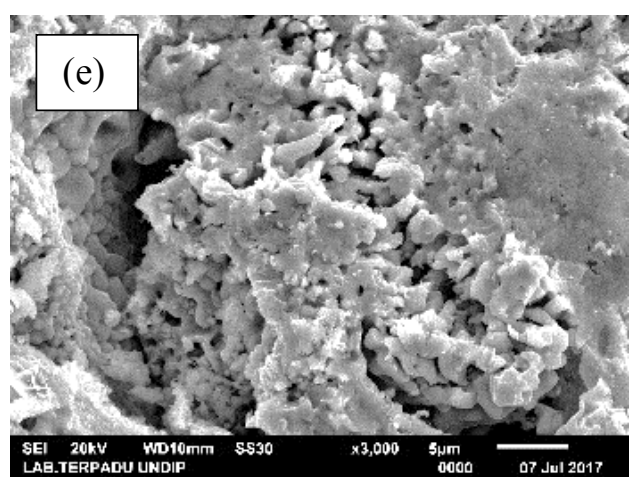

Fig. 7 . SEM micrographs of (a) CuZn 0 wt.\%, (b) CuZn 10 wt.\%, (c) CuZn 20 wt.\%, (d) CuZn 30 wt.\% and (e) CuZn 40 wt.\%.

Based on ZAF Method Standardless Analysis for chemical composition test obtained that $\mathrm{CuO}=32,05 \%$, $\mathrm{ZnO}=23,58 \%, \mathrm{C}=10,34 \%, \mathrm{Al}_{2} \mathrm{O}_{3}=10,27 \%, \mathrm{SiO}_{2}=$ $10,08 \% \mathrm{FeO}=4.49 \%, \mathrm{SnO}_{2}=3.33 \%, \mathrm{TiO}_{2}=3.07 \%$ and $\mathrm{ZrO}_{2}=1.36 \%$.

According to the observation by SEM as shown at Figure 7. The porous ceramic membranes at $0 \mathrm{wt} \%$ $\mathrm{CuZn}$ shows a small porosity if compared with other samples. In all the addition of $\mathrm{CuZn}$ on porous ceramic membranes will change the appearance of ceramic surface becomes more porous. This data was supported with the porosity data in Figure 5. Its can be seen in the $\mathrm{CuZn}$ content of $10 \mathrm{wt} . \%$ indicated the largest amount of porosity and gradually. While the adding more $\mathrm{CuZn}$ and slighlty causing the low porosity.

Our special gratitude to the DRPM KemenristekDikti and Mechanical Engineering at Universitas Muhammdiyah Semarang on the facilities provided to us by Research at PENELITIAN PRODUK TERAPAN (PPT) in 2017.

\section{References}

1. Manohar, IJMER. 2, 4, 1492 - 1506 (2012)

2. D. S. Biron, J. Bortoluz, M. Zeni, C. P. Bergmann and V. Santos, Mater. Res., 19, 3 (2016)

3. F. T. Owoeye, A. P. Azoda and S. B. Udo. J. Mech. Eng. Sci. 7, 1115 - 1126 (2014)

4. P. Hristov, A. Yoleva, S. Djambazov, I. Chukovska and D. Dimitrov. J. Univ. Chem. Tech. and Metal., 47, 4 pp. 476-480 (2012)

5. A. A. Hosseini, A. Sadigzadeh, S. Mohammadi and R. Soltani, Iranian Journal of Materials Science \& Engineering, 8, 3 (2011)

6. A. Harabi, A. Guechi and S. Condom. Proced. Eng. 33 220-224 (2012)

7. P. Hristov, A. Yoleva, S. Djambazov, I. Chukovska and D. Dimitrov, Journal of the University of Chemical Technology and Metallurgy, 47, 4 pp. 476-480 (2012)

8. C. Mangkolkachit, S. Wanakitti and P. Aungkavattana, Journal of Metal, Materials and Minerals, 20, 3 pp. 123-125 (2010) 
9. P. Monash, Pugazhenthi and P. Saravanan, 2013, Rev. Chem. Eng., 29 (5) pp.357-383 (2013)

10. P. Fan, K. F. Zhen, Z. Y. Zan, Z. Chao, Z. Jian and J. Z. Yun, Chem. Eng. Trans., 55, 277-282 (2016).

11. F. T. Owoeye, A. P. Azoda, and S. B. Udo, J. Mech. Eng. Sci. 7, pp.1115-1126 (2014) 